\title{
Mapping of the Sweet Potato Value Chain Linkages between Actors, Processes and Activities in the Value Chain: A Case of "Michembe" and "Matobolwa" Products
}

\author{
Joel Johnson Mmasa (Corresponding author) \\ School of Economics and Business studies \\ Department of Economics of University of Dodoma \\ PO box 259, Dodoma, Tanzania \\ Tel: 255-232-604-402 E-mail: joel_mmasa@yahoo.co.uk \\ Elibariki Emmanuel Msuya \\ Department of Agricultural Economics and Agribusiness \\ Sokoine University of Agriculture \\ PO box 3007, Chuo Kikuu, Morogoro, Tanzania
}

Received: November 14, 2011

Accepted: December 21, $2011 \quad$ Published: February 1, 2012

doi:10.5539/sar.v1n1p130

URL: http://dx.doi.org/10.5539/sar.v1n1p130

\begin{abstract}
The objective of the study was to map sweet potato value chain linkages between actors, processes and activities in Tanzania. The study is cross sectional in design.The study was conducted in Shinyanga rural and Mwanza urban districts. The study used individual interviews, focused group discussions; review of relevant practical documents and discussions with key informants. A total of 150 actors in the value chain participated. Data collected was summarized using Statistical Package of Social Science (SPSS) and content analysis. Analysis of data shows that "Michembe" and "Matobolwa" were two main local made value added products derived from sweet potatoes preferred by producers. In general sweet potatoes production is marked with low production and productivity. Low productivity is a result of poor agronomic practices and low level of production technology application among others. Three main marketing channels exist in the study area: Producers selling directly to consumer; producers to retailers to consumer; and producers to hawkers/village vendors to consumer. Moreover data revealed that (50.7\%) of sampled producers set prices after hearing from their fellow farmers. About (44\%) of the sampled producers sell their produce direct to the market. The sub sector in general faces a number of structural and technological problems that need immediate attention to revamp agricultural sector development.
\end{abstract}

Keywords: Sweet potato, "Michembe" and "Matobolwa", Value chain, Mapping

\section{Introduction and Background Information}

\subsection{Background to information}

Sweet potato ipomoea batatas is a major staple food and income source in several regions of Tanzania and elsewhere in East Africa and under-exploited food crops (Ndunguru, 2003). Sweet potatoes are grown in most parts of the country, but main production zones are found in Lake Zone, Southern Highlands and Eastern Zone (URT, 2007).

Because of its versatility and adaptability, sweet potato ranks as the world's seventh most important food crop after wheat, rice, maize, potato, barley, and cassava, as it constitute a substantial source of carbohydrate and carotene (CIP, 2000; FAO, 2002). According to the Food and Agriculture Organization (FAO) statistics, world production in 2004 was 127 million tonnes of sweet potatoes majority of which came from China, with a production of 105 million tonnes. Nearly half of the sweet potato produced in Asia is used for animal feed, with the remainder primarily used for human consumption, either as fresh or processed products. 
Cognizant, Sub-Saharan Africa produces more than seven million tonnes of sweet potatoes annually, which constitutes $5 \%$ of global production (Ewell, 2002). African's top producers of sweet potatoes are Uganda (1.7 million tonnes) and Nigeria (1.6 million tonnes) followed by Tanzania (1.3 million tonnes) (FAO, 2004). Moreover, sweet potatoes play an essential role for food security, especially in those regions prone to drought and with poor soils like Shinyanga and Kagera in Tanzania (FAO, 2004). In contrast to Asians countries, in sub-Saharan Africa, the crop is cultivated mainly for human consumption. African yields are quite low about a one third of Asian yields indicating huge potential for future growth.

Sweet potato is a co-staple in East Africa's densely populated, intensively cultivated mid-elevation farming areas and it is an important secondary crop grown for an expanding unmarked market (FAO, 2004). However its utilisation is remarkably narrow in East Africa. The crop is most often consumed boiled or roasted in the fresh form; however vines are fed to livestock particularly in areas like central Kenya where small-scale dairying in zero grazing management systems is well developed. They are also being used as starter feed and partial milk replacer for young calves (Orodho et al., 1995). The limited range of ways and availability of adapted processing technologies in which sweet potato is utilized in the region seriously undermine the potential benefits of the crop to farmers and consumers and other chain actors.

In Tanzania sweet potatoes are grown mainly for survival, the average yield of sweet potatoes is approximately 5 -6 metric tons per hectare on dry weight basis, however the low yield in Tanzania is caused by many factors including susceptibility to pests and diseases, declining soil fertility, moisture stress, low level of crop husbandry and management and poor accessibility to markets (Nduguru, 2003). However in Zimbabwe the national average yield of the crop is 6 tons per hectare with wide yield variations of up to 25 tons per hectare for sweet potatoes grown under irrigation. While this compares well with Africa's yield average of $6 \mathrm{t} / \mathrm{ha}$, it is below the global average yield of $14 \mathrm{t} / \mathrm{ha}$ and a yield potential of $18 \mathrm{t} / \mathrm{ha}$ (Smith, 2004).

Total production of sweet potatoes in the Lake Zone has reached 100,000 (URT, 2004). In the lake zone Shinyanga and Mwanza Regions is by far the major sweet potatoes production area in Tanzania (ibid). Taking into account that Shinyanga rural district have reached around 28428 MT (DALDO, 2010). However the crop commands both low domestic and international demand, a situation attributed to a poor marketing and distribution system (FAO, 2003). This in part can be attributed to limited consumption, processing and storage options for the crop (FAO, 2003). Moreover in the lake zone of Tanzania traditionally grows sweet potato and it appears that some indigenous post-harvest methods are also practiced. These, however, have not been comprehensively documented.

Literature on use of root and tubers like sweet potatoes value added a product is scanty. "Michembe" and "Matobolwa" are the value added products derived from sweet potato (Mpagalile et al., 2007). This products looked promising in broadening market potential for wider transect of the Tanzanian community but needed improvement in processing technology, quality and sensory attributes to improve its acceptability.

\subsubsection{Value chain analysis}

Value chain analysis is a powerful tool for managers to identify the key activities within the firm which form the value chain for that organization, and have the potential of a sustainable competitive advantage for a company. Therein, competitive advantage of an organisation lies in its ability to perform crucial activities along the value chain better than its competitors. The value chain framework of Porter (1990) is "an interdependent system or network of activities, connected by linkages" (p. 41). When the system is managed carefully, the linkages can be a vital source of competitive advantage (Pathania, 2001). The value chain analysis essentially entails the linkage of two areas. Firstly, the value chain links the value of the organisations' activities with its main functional parts. Then the assessment of the contribution of each part in the overall added value of the business is made (Lynch, 2003).

But according to Seminar für Ländliche Entwicklung (SLE) publication series (2008) the value chain is a development concept with two main perspectives (Koenig et al., 2008); Functional role; a value chain is a series of related business activities-starting with a provision of specific inputs, production processing, marketing and finally, consumption and other concept as Institutional perspective; value chain is a set of players/institutions performing function under (a) above which are linked with series of business transaction.

Similarly, Gibbon (2001) described a value chain as a chain of activities, where products pass through all activities of the chain in that order and at each activity, the product gains some value. The chain of activities gives the products more added value than the sum of added value of all activities. The author further observes that it is important not to mix the concept of value chain with the cost occurring throughout the activities. For example, careful sweet potato production, harvesting, handling, preservation, processing and storage activities by 
avoiding pests, bruises, cuts may have a cost through the use of agronomical practices including use of pesticides, purchase of special processing and storage facilities but the activity relatively add much of the value of the end products, since sweet potato affected by pests with bruises or broken pieces have lower value than the wholesome ones without damage or bruises.

The ability of a company to understand its own capabilities and the needs of the customers is crucial for a competitive strategy to be successful. The profitability of a firm depends to a large extent on how effectively it manages the various activities in the value chain, such that the price that the customer is willing to pay for the company's products and services exceeds the relative costs of the value chain activities. It is important to bear in mind that while the value chain analysis may appear as simple in theory, it is quite time-consuming in practice. The logic and validity of the proven technique of value chain analysis has been rigorously tested, therefore, it does not require the user to have the same in-depth knowledge as the originator of the model (Macmillan et al., 2000).

The first step in conducting the value chain analysis is to break down the key activities of the company according to the activities entailed in the framework. The next step is to assess the potential for adding value through the means of cost advantage or differentiation. Finally, it is imperative for the analyst to determine strategies that focus on those activities that would enable the company to attain sustainable competitive advantage.

Michael Porter (1990) designed the analysis to examine organizational production and support processes and their contributions towards developing greater competitive advantage. Porter argued that competitive advantage could not be understood simply by looking at a firm as a whole. It stemmed from the many discreet activities a firm performs in designing, producing, marketing, delivering and supporting its product. Over the years firms have used his framework to help them: Identify the actual activities performed by business units; Analyze the value created by these individual activities; Examine how linkages and flows to external buyers and suppliers build value as successive processes occur; Map the exchanges of flows into and out of the organization; Identify activities that are key to success of strategy a and Understand resource allocations with a view to allocating resources in accordance with the contributions of the task to strategic direction. Performing these function, value chain analysis can then be used to identify and strengthen those activities which most contribute to overall strategy while constraining resources allocated and consumed by tasks less critical.

It is fair to say that Porters initial framework adds tremendous value to our ability to understand relationships between buyers and suppliers, but as he admits it has its limitations. Porter advises against "applying value chain analysis at too high a level in an organization." He argues an industry will contain many different segments which imply the need for different processes and which involve different economic relationships and dynamics. Therefore, Porter's value chain analysis works well to assess static relationships between participants, but falls short of letting us understand the dynamics associated with high clock speed industries that continuously redefine their value chain relationships. Understanding these limitations, we set out to analyze the sweet potatoes value chain and create a framework that will allow us to formulate these economic relationships and the dynamics that drive changes within both the device and infrastructure value chain.

In order to conduct the value chain analysis, the company is split into primary and support activities (Figure 3). Primary activities are those that are related with production, while support activities are those that provide the background necessary for the effectiveness and efficiency of the firm, such as human resource management.

The primary activities (Porter, 1985) of the company include the following: Inbound logistics: These are the activities concerned with receiving the materials from suppliers, storing these externally sourced materials, and handling them within the firm. Example, seeds and pesticides from input supplies stockiest. Operations: These are the activities related to the production of products and services. This area can be split into more departments. For example, the operation in case of sweet potatoes industry includes farm preparation (ridging, planting, weeding, harvesting, handling, processing etc; Outbound logistics. These are all the activities concerned with distributing the final product and/or service to the customers. For example, in case of a sweet potatoes industry activity would entail the ways product is sold to customer, customer care costs and handling; Marketing and sales. This functional area essentially analyses the needs and wants of customers and is responsible for creating awareness among the target audience of the company about the firm's products and services. Companies make use of marketing communications tools like advertising, sales promotions etc. to attract customers to their products and Service. There is often a need to provide services like pre-system or after-sales service before or after the sale of the product or service.

Support activities of a company include the following: Procurement. This function is responsible for purchasing the materials that are necessary for the company's operations. An efficient procurement department should be 
able to obtain the highest quality goods at the lowest prices. Not applicable in the household level for farming activities; Management. This is a function concerned with recruiting, training, motivating and rewarding the workforce of the company.

Human resources are increasingly becoming an important way of attaining sustainable competitive advantage; Technology Development. This is an area that is concerned with technological innovation, training and knowledge that is crucial for most companies today in order to survive. It is very important for the farmer to be equipped with modern technology in production and processing, packaging of the value added products and Firm Infrastructure. This includes planning and control systems, such as finance, accounting, and corporate strategy etc. (Lynch, 2003) .Famers should be trained on the importance of keeping records of production costs so that they can latter associate with earnings and profit accrued from that particular business. Porter used the word 'margin' for the difference between the total value and the cost of performing the value activities (Figure 3). Here, value is referred to as the price that the customer is willing to pay for a certain offering (Macmillan et al, 2000). Other scholars have used the word 'added value' instead of margin in order to describe the same (Lynch, 2003). The analysis entails a thorough examination of how each part might contribute towards added value in the company and how this may differ from the competition.

\subsection{Problem Statement and Justification}

\subsubsection{Problem Statement}

Sweet potato in Tanzania ranks twelveth by value and sixth by quantity (FAO, 2007). The crop provides employment and it is important in sustaining food security and livelihood for the rural poor (ibid). Sweet potato in Tanzania is grown as a subsistence crop for food security and as a cash crop (URT, 2005). Mwanza and Shinyanga region are the leading producers of sweet potatoes in the lake zone (URT, 2007). Moreover according to Shinyanga District Agricultural and Livestock Development Officer (DALDO) reported that from 2005/06 to 2009/10 (Table 13) production records show an increasing and decreasing trend (DALDO, 2010).

Like other crop famers, sweet potato farmers depend on rain fed for production and therefore produce at the same time (after the rain season), leading to a surplus of sweet potatoes soon after harvest and to a shortage in the dry season (Anon, 2003). In other words, there is lack of supply coordination between farmers in order to meet continuous market demand. Bulkiness and perishability affects post-harvest system of sweet potatoes as it has a shelf-life of little more than one week after harvesting (Abidin, 2004). Hence is both desirable and necessary to process sweet potato into storable products (Ndunguru, 2001). In other words value addition is necessary if Tanzania is to enjoy higher benefits from the crop. Sweet potatoes are mainly boiled or roasted and very little attempt has been done to make flour or crips (Ndunguru et al., 2003). However what is not well known is mapping of the subsector. Many actors in the value chain are not aware of the many value addition possibilities of sweet potatoes in Tanzania. Before investing in value addition of sweet potatoes, it is important to investigate market potential for sweet potatoes value added products.

\subsubsection{Justification}

The study is in line with Millennium Development Goals (MDGs) Goal 1: Eradicate extreme poverty and hunger to reduce hunger and poverty. The target 1.A: Halve, between 1990 and 2015, the proportion of people whose income is less than one dollar a day.

Moreover the study is also in line with National Strategy for Growth and Reduction of Poverty (NSGPR) "MKUKUTA" programme in reducing the prevalence of income poverty in Tanzania of which according to the household budget survey of 2000/01 the proportion of population below the national basic needs such as food, shelter and water is $35.7 \%$ (URT, 2005). Interesting the study fit in the current National program known as Comprehensive Africa Agriculture Development Plan (CAADP) signed at Maputo in 2004 by the heads African states, in the country the program will be implemented under Tanzania Agricultural Food Security Investment Plan (TAFSIP) objective is to combat the problem of food insufficiency in African countries.

\subsection{Objectives}

\subsubsection{Overall Objective}

The overall objective is to improve the welfare of the rural poor by diversification and expansion of sweet potato value added products.

\subsubsection{Specific Objectives}

i. To map the sweet potato value chain linkages between actors, processes and activities in the value chain. 
ii. To recommend to policy makers on how to promote agricultural value added products.

1.3.3 Research Questions

i. What are the sweet potato linkages/relationship that exists between actors, processes and activities in the value chain?

\subsection{Significance of the Study}

The following are the significance of the study.

i. The study is important because it acts as a mirror to Tanzania as a whole on looking and assessing market potential of value added products in boosting economy of the rural people.

ii. This study will bring more influence to policy markers on how to review the existing policies for interest of all key actors in marketing of agricultural products.

\section{Methodology}

\subsection{Research Design, Sampling Unit, Sample Size and Sampling Techniques}

This study used a cross-sectional in research design. Under this design, data from household's respondents was collected at a single point of time without repetition from the representative population. The study included producers/processors, traders and consumers of sweet potatoes products with various characteristics. Generally, the study covered 150 respondents altogether. The researcher applied two types of sampling procedures namely of simple random sampling and Judgmental /purposively sampling. The sampling unit for this study was constituted of consumers, producers (farmers), processors and traders of sweet potatoes both retail and whole sellers. The sample size was 150 respondents. The sample size is reasonably large especially in conformity with Bailey (1994) argument that around 30 cases seems to be the bare minimum for studies in which statistical data analysis is to be done.

A multi-stage technique was used; the first stage involved the selection of wards and villages using purposively sampling technique from which producers and traders was obtained. The choice of wards and villages was based on volume of production of sweet potatoes, accessibility and communication. Selection of wards and villages was done during pre-survey. To obtain the representative sample for the study, purposively/judgmental sampling technique was used to obtain wards. This technique has been recommended in social research by Kothari (2004) as it focuses directly to the area intended to be studied. The second stage was involved selection of different categories of respondents within value added product chain. Both probability and non-probability sampling techniques were employed to select respondents.

\subsection{Selection of Producers/Traders}

List of potential sweet potatoes producers both small scale and medium scale were obtained from village extension officers formed the basis for selection of sample sweet potatoes producers. In the first stage involve systematic random sampling was used to select respondents from small scale category while purposively sampling was used to select medium scale producers.

\subsection{Selection of Traders}

Traders were purposively selected from the list of traders obtained from the heads of markets (Chairperson and Secretary) who had names of trading partners and their locations. Hence were purposively selected and interviewed at their premises. Sampling frame of hawkers and their localities was obtained from producers/processors.

\subsection{Selection of Consumers}

Food products produced within and around Shinyanga mainly reach the consumers through direct producer to consumer sales or via retail outlets such as local market place. This is because production of many of agricultural products depends on crop calendar. Hence random sampling was employed to obtain consumers.

\subsection{Methods of data Collection}

Both primary and secondary data collection methods were used to obtain sufficient and realistic information and justification to the findings. This method included questionnaires, interviews, observation and documentation. A structured and semi-structured interview was administered to producers/farmer, processors and traders and consumers. 


\subsection{Secondary Data}

These data obtained from literature sources or data collected by other people for some other purposes. Thus secondary data provide second hand information and include both raw data and published ones (Saunders et al., 2000). Secondary data was collected from the following sources; Shinyanga region and District agricultural offices, Sokoine National Agricultural Library (SNAL), Tanzania bureau of statistics, Dar-Es-Salaam university library and other sources relevant to the study and websites was explored.

\subsection{Data Analysis and Interpretation}

The data collected was analyzed and interpreted to enable readers to understand the results. Data analysis refers to the computation of certain measures along with searching for patterns of relationship that exist among data groups, (Kothari, 2004). The process of data analysis involved editing, coding and interpretation so as to ensure accuracy, and relevancy to the study. Both qualitative and quantitative data analysis methods were be involved. That is, the researcher used descriptions of the facts, to show the relationships of variables. The researcher used tables, graphs and some in charts for the descriptive information in order to make them understandable. Data collected from the primary sources was coded and entered in Statistical Package for Social Sciences (SPSS).

\subsection{Sub-sector Mapping Analysis}

Sub-sector mapping analysis was used to map the sweet potato value chain linkages between actors, processes and activities in the value chain. Visualize networks in order to get a better understanding of connections between actors and processes in a value chain, demonstrate interdependency between actors and processes in the value chain and create awareness of stakeholders to look beyond their own involvement in the value chain (Michael et al., 2010).Qualitative data was analyzed by content/context analysis.

Sub-sector mapping analysis used to map the sweet potato value chain linkages between actors, processes and activities in the value chain. The aim is to visualize networks in order to get a better understanding of connections between actors and processes in a value chain, demonstrate interdependency between actors and processes in the value chain and create awareness of stakeholders to look beyond their own involvement in the value chain (ibid).

\subsection{Ethical Contemplation}

In this work, a research take into consideration the issue of confidentiality at all the time in the way that unauthorized persons were not in position to have access to the data collected and the identity of the respondents remained on the researcher knowledge, this has been done in efforts of protecting the subjects. The issuer of voluntariness was also observed as respondents participated in the research voluntary no one was forced into participation.

\subsection{Data Quality}

\subsubsection{Reliability}

The consistency with which repeated measures produce the same results across time and across observers refers as reliability (Patton, 2000).To ensure reliability, this study employed three methods of data collection namely questionnaires, documentary reviews and interviews.

\subsubsection{Validity}

Babie (1992) define the term validity to mean that, the extent to which the concept one wishes to measure is actually being measured by a particular scale or index; that is the extent to which an account accurately represents the social phenomena to which it refers. To ensure validity of measures, the data were gathered from various categories of respondents, including producers, processors, traders and consumers of various characteristics. Moreover date was also collected form Shinyanga region and Mwanza region and District agricultural offices, Sokoine National Agricultural Library (SNAL), Tanzania bureau of statistics, Dar-Es-Salaam university library and other sources relevant to the study and websites was explored. Primary data on specific issues of the study coincide with the secondary data.

\section{Results}

\subsection{Introduction}

This section presents the results of the study: Results are presented in various forms including percentages, statements, tables and figures. Results presented are based on the objectives of the study and study questions. Discussion follows immediately to interpret the trend shown by the results and the reasons thereof. 


\subsubsection{Characteristics of Sampled Sweet Potatoes Producers}

The results revealed that (42\%) of the sampled respondents aged was ranged from 14 years to 68 years and majority of the respondents were in between 31-40 years old (Table 1). This showed that the respondents were in active age to engage in production. Regarding to gender the data revealed that $55.3 \%$ were female and $44.7 \%$ were male, one can conclude that women engage more in sweet potato production than male (Table 2). Furthermore results in table 3 showed that majority of the household respondents were married $(86 \%)$ hence married obliged to take care of their family hence participation in farming is compulsory. Regarding to education level $(69.3 \%)$ spends $4-7$ years in schooling (Table 4$)$, hence attain universal primary education. This indicates that most of them were adults who can handle adult's responsibility including farming and livestock keeping for caring their family for livelihood survival.

\subsection{Sweet Potato Production and Land Size}

Table 5 indicated that farmers produce a minimum of $42 \mathrm{~kg}$ to $8100 \mathrm{~kg}$ as maximum of processed sweet potato products. Moreover one bag weighed up $(140-160 \mathrm{~kg})$ in wet basis after harvesting ready for market. However when if processed can give up to $60 \mathrm{~kg}$ of processes sweet potato. The main products produced are "mapalage" and "michembe". However the same famers consume an average of $12019 \mathrm{~kg}$ per season of processed sweet potatoes. Furthermore majority of farmers owned an average of $1-15$ acres $(85.3 \%)$ for farming of all crops hence the area seems to have no problem of land tenure (Table 6). This data appealed that that the produce is not able to sustain even for consumption purposes to lift the farmer to the next harvesting season because consumption is higher than what harvested, hence it is common that majority of household becomes food insufficiency and copping mechanism is to labour out hence they become more vulnerable. If research on sweet potato products is made more effective, perhaps sweet potato can be used to close the African food gap. In Tanzania, according to recent study the average yield of sweet potatoes in Tanzania is 6 metric tons per hectare $(6000 \mathrm{~kg})$ on dry weight basis (Smith, 2004). Because of poor market linkages, inadequate information and poor infrastructure, decisions concerning prices of sweet potato products are decided by few players in the value chain. The middlemen, retail traders and end users of sweet potato products control the sweet potato market.

\subsection{Value Added Products Derived from Sweet Potatoes}

Process flow diagram for producing dried sweet potato chips to "michembe" is summarized in Figure 1. Process flow diagram for producing dried sweet potato chips to "matobolwa" is summarized in Figure 2.

\subsection{Farming Tools}

Majority of the sampled respondent used rudimental farming tools especially hand hoe (80.7\%) and only (19.3\%) of the respondents had used oxen plough for cultivation (Table 7). Uses of traditional technologies in production retard production, efforts are needed to train famers on the use of improved agronomical practices to increase their agri-business profitably. Conversely majority of the sampled respondent used to buy local seeds for planting from their fellow farmers. Although it was noted that few famers used to grow reserved seed in their wet areas.

\subsection{Common Seeds/Vines Used}

Majority of the surveyed respondents/producers (99\%) used a local seeds in production of sweet potato, namely lyochi, umeme, selena, mwanamakinu, pipi, bugoi, nyahinga, kalamu ya mwinyi, mwanamke hana siri, lukuba, mwana bundala, sinia la mwanza few to mention. These local seeds were selected for sowing based on the following options; early maturity, potential production (size of the product produces and quantity) and disease resistance. None of the farmers used improved seeds. This implies that efforts are needed to mobilize farmer on the rationale of using improved seeds to boost production.

\subsection{Costs for Making Ridges}

Cost for making ridges ranged from TAS 1500 as a minimum to TAS 100000 per acre while famers used TAS 1000 to TAS 60000 is used to plant one acre. Meanwhile harvesting can costs up to TAS 40000 per acre (Table $8,9 \& 10)$.

\subsection{Market Information}

Results presented in table 11 showed that $(50.7 \%)$ of interviewed sampled producers set prices after hearing form their fellow farmers. Meanwhile (44\%) of the interviewed sampled producers said they visit market direct to know the price and one percent of the interviewed producers said they receive price information from NGOs like World Vision Tanzania and other sources. One may conclude that majority of producers sold their sweet potatoes products after hearing from their fellow friends or direct visit to the market. 


\subsection{Input Accessibility}

Survey results showed that $70 \%$ of the sampled producers do not have access to or they don't need inputs and extension services for sweet potatoes production. Contrary 19.3\% reported to have received extension services from extension officers and the rest from other sources (Table 12). This indicates that farmers had never received extension services from village extension officers hence more effort is needed from Local Government, NGOs and other civil society organizations to support sweet potato sub-sector in order to improve sweet potato production.

\subsection{Key Players in the Value Chain}

Key players of sweet potato (sweet potato-sector in particular) in Tanzania comprise a number of participants (actors).As described in the manner below.

- Producers/processors

- Small Traders

- Rural hawkers

- Processors

- Retailers

- End users

- Input suppliers

- Local Seed Stockiest

\section{Discussion}

\subsection{Preamble}

A product channel refers to route followed by products as it moves from producers to a consumer. Thus value chain analysis is intended to provide a systematic knowledge of the flow of goods and services from their origin (producer) to their final destination (consumer). This knowledge is acquired by studying the participants/key actors in the value chain i.e. those who perform physical marketing functions in order to obtain economic benefit. There are successive functions which have to be performed by market agents/intermediaries through which they achieve both personal and social goals by earnings a personal financial award. In so doing they add value to products and satisfy the consumers needs. The channels, thus, vary in their efficiency e.g. in terms of profitability to actor, quantity moved or transformed.

\subsection{Sweet Potato Value Chain Analysis}

The sweet potato value chain analysis involved a number of functions and institutions. It has both backward and forward integrations. Small holder farmers as growers are at the central point. Farmers are linked with input suppliers (backward integration). The inputs include sweet potato seeds, fertilizers, and chemicals. Other linkages with sweet potato growers involve oxen and tractors owners who do farm tillage operations for farmers.

After harvesting sweet potato roots (fresh), farmers process to "Michembe" and "Matobolwa", a number of routes are involved in the forward integration. In order to reach sweet potatoes consumers, farmers may sell directly to the consumers or sell through the middlemen or village hawkers. Under this route, transporters have a function of transporting fresh sweet potato or value added products to the retailers or consumers. In Shinyanga, producers play a double role as a producer and processor in other hand, processing is done at small scale level and some few farmers do own ox-carts. The current business practice in the dried sweet potato supply chain is through spot transaction relationships between traders, middleman and farmers.

Processors who are producers also have no linkages with suppliers of machineries, utility suppliers, spare parts and packaging materials. There a number of activities involved after production of "Michembe", "Matobolwa" by processors. The activities include-transporting, retailing and distribution. In many places of Tanzania growers do process products from sweet potato for home consumption in the future use.

Sweet potato products and fresh sweet potato as products have end markets all over Tanzania and all countries around Eastern and Southern Africa (Kenya, Uganda and Burundi).The market trends for the sweet potato products is not fully utilized and local production cannot meet the demand. However in Shinyanga and Mwanza many end consumers prefer processed products. In Nigeria two primarily products were generated locally called inginyo and amukeke; it is from further processing of these that two secondary products (amukeke flour and inginyo flour) were derived (Engoru et al., 2005). 
China is the leading potato producer followed by Uganda and Nigeria. However Tanzania ranked number $6^{\text {th }}$ in the world and $3^{\text {rd }}$ in Africa with production of 1.3 Million tonnes (FAO.2010). Sweet potato is grown throughout the world. However, only about one percent of production enters world trade with Canada, the United Kingdom, France and the Netherlands being the major importing countries. Conversely USA is the largest exporter of Sweet Potato accounting for $35 \%$ of world trade (41 000 MT). Other exporters are China 16000 MT (12\%), Israel is the $3^{\text {rd }}$ with capacity of exporting $12000 \mathrm{MT}(9 \%)$, France (7\%), Indonesia (6\%) and Netherlands (5\%). Most of the product is used for table consumption with a small percentage going into industry uses and animal feed (FAO, 2010). Furthermore United State of America (USA) is the leading sweet potato earners with total value of more than 37 million US \$ followed by France and Israel (FAO,2010). Surprisingly Tanzania earns about one million US $\$$ from sales of sweet potatoes.

\subsection{Key players and their core functions in the value chain}

As said earlier in this paper according to SLE publication series (2008) the value chain is a development concept with two main perspectives; Functional role; (i) a value chain is a series of related business activities-starting with a provision of specific inputs, production processing, marketing and finally, consumption and Institutional perspective; (ii) value chain is a set of players/institutions performing function under (i) above which are linked with series of business transaction (Koenig et al., 2010).

Key players of sweet potato (sweet potato-sector in particular) in Tanzania comprise a number of participants (actors). As described in the manner below.

Producers: Usually producers of sweet potato sell part of their processed sweet potato to traders or fellow farmers with food shortages within the villages or nearby villages. The amount sold varies by the size of sweet potato fields, amount harvested and food requirement of household (quantities of cereals).

They sell processed sweet potato in auction each Sunday during season and off season the year depending on the household's cash needs. They sell individually in various forms including fresh sweet potato (unpeeled roots) for consumption, dried sweet potato per tin or sack ("Michembe" and "Matobolwa") and processed into floor.

Producers who are processors also sell processed products ("Michembe" and "Matobolwa") at household home or at the village-open markets (auction) every Sunday to end users consumers. Usually producers have access to marketing information on prices by direct visit to auction or hearing from their fellow friends.

Bargain is mostly on an individual basis. They do not make any pre-arrangement with vendors or traders in selling their sweet potatoes. Also, very interesting story, Producers play a dual role as a processors also, you can't separate characteristics and functions of the two actors.

Rural hawkers: Sweet potato vendors are few in numbers and not widely available in the region but they are not organized in business arena. Rural vendors/hawkers buy dried sweet potato or fresh direct from farmers. They are inadequate by capital and know where to sell. Their major transport means is bicycle and or by hiring handcart or pushcart/ox-carts

Small Traders: Practically no small traders involving in this business. The reason could be due to limited information on production and marketing of sweet potato.

Processors: They are also sweet potatoes growers per see mainly engaged in processing of fresh sweet potato to "Michembe and Matobolwa". At present they have very limited technologies on processing of sweet potato as their raw materials in producing products. The work is done manually at small scale level no idea to scale up the technology. They are not aware of the benefits of the sweet potato products

Retailers: There are both urban and rural retailers involve in selling fresh and /or dried Sweet potato. Their selling points are at town markets, at village centres and along road sides. They buy from farmers or big traders in Kahama or Bukombe Districts. They manage only small quantities such as $300 \mathrm{~kg}$ (3bags) to $10000 \mathrm{~kg}$ (10bags) of fresh sweet potato per trip for up to 7 days of selling. In additional they process the product at the market place to avoid decaying of the produce due to shorter shelf life. Retailers can buy Sweet potato from farmers

End users/Consumers: Consumers from local and regional markets for the case michembe and matobolwa and byproducts as livestock feed.

Input suppliers are not vertically integrated with producers, framers normally search seeds for planting from their fellow farmers not from recognized source/agent. There is farm gate levy which producers pay fees before transporting the products to the buyers. However, suppliers of machine, spare parts and packaging materials do not interact with producers/processors at all and R\&D is not vested to this crop unlike other roots crops. 
Research and Development is important factor that the Tanzania needs to invest for the development of new technology. Commission for Science and Technology (COSTECH) should be capacitate to undertake this role.

\section{Conclusion and Recommendation}

Results of this study showed a possibility of producing other products from sweet potato. Sweet potato enterprise in Shinyanga District faced different constraints in production and marketing, which limit development and sustainability of the industry. Generally the industry plays a significant role in contributing to social economic development of the people in District. Popularization and promotion work need to target areas that use sweet potato within and outside the study districts. As a way forward in promoting sweet potato utilization, new value-added products are needed to develop newer uses of sweet potato, like "Michembe" and "Matobolwa".

\section{Acknowledgements}

The authors greatly acknowledge financial support by High Education Students Loan Board (HESLB) and the United Republic of Tanzania. The University of Dodoma (UDOM) and the key actors in sweet potatoes value chain for participating in the mapping work.

\section{References}

Abidin, P. E. (2004). Sweet potato breeding for northeastern Uganda: Farmer varieties, farmer-participatory selection, and stability of performance. PhD Thesis, Wageningen University, The Netherlands, 152. ISBN: 90-8504-033-7.

Anon. (2003). Storing sweet potato made simple. Dissemination Leaflet. Natural Resources Institute, Tanzania Food and Nutrition Centre and Lake Zone Agricultural Research and Development Institute. 2.

Bailey, K. (1994). Methods of Social Research. Fourth Edition. The free press. A Division of Macmillan Inc., New York. 588.

Classification of Instructional Programs (CIP), (2000). Effect of Women Farmers Adoption of Orange Fleshed Sweet Potatoes: Stories From Fields: International Potatoes Center Annual Report 2000. CIP Annual Report International Potatoes Center.

District Agricultural Development Plans (DADPS). (2010). Shinyanga Rural District Council Plan, Shinyanga, Tanzania.

Engoru, P., Mugisha, J., \& Bashaasha B. (2005). A characterisation of tuber utilisation among sweet potato producers in eastern Uganda. African Crop Science Conference Proceedings, 6, 726-731. Printed in Uganda. ISSN 1023-070X/2005. African Crop Science Society.

Ewell, P. T. (2002). Sweet potato production in Sub-Saharan Africa: Patterns and key issues. Nairobi, Kenya: CIP.

Food and Agricultural Organization (FAO). (2003). Production year book. vol.57. FAO, Rome.

Food and Agricultural Organization (FAO). (2004). FAO Statistics. Food and Agriculture Organization, Rome, Italy [http:www.apps.fao.org] site visited on $30 / 10 / 2010$.

Food and Agricultural Organization (FAO). (2002). FAO Statistics. Food and Agriculture Organization, Rome, Italy [http:www.apps.fao.org] site visited on $29 / 10 / 2010$.

Food and Agricultural Organization (FAO). (2007). FAOSTAT Data. Food and Agriculture Organization, Rome.[http:www.faostat.external.fao.org/default.jsp] site visited on 25/4/2010.

Food and Agricultural Organization (FAO). (2010). FAOSTAT. Food and Agriculture Organization, Rome, Italy [www.http://faostat.fao.org/default.aspx, 2010].Site visited on $30 / 5 / 2011$.

Gibbon, P. (2001). Agro-Commodity chains: An introduction. IDS Bulletin, 32(3), 60-67. http://dx.doi.org/10.1111/j.1759-5436.2001.mp32003007.x

Gilsing, Victor. (2000). Preliminary Draft: Cluster Governance, how clusters can adapt and renew over time. Paper prepared for the DRUID-PhD Conference, 2000. Copenhagen Available from: http://www.druid.dk/conferences/winter2000/gilsing.pdf.

Knorringa, Peter. (2002). Urban Cluster Trajectories in Developing Countries: Beyond the Industrial District Model. In: I.S.A. Baud and J.Post (eds) Realigning Actors in an Urbanizing World, Governance and Institutions from a development Perspective, Department of Geography and Planning, University of Amsterdam, Ashgate, England. 63-78. 
Kothari, C. R. (2004). Research Methodology-Methods and Techniques, $2^{\text {nd }}$ Edition, K.K. Gupta for New Age International (P) Ltd. New Delhi, 288.

Lynch, R. (2003). Corporate Strategy, 3rd ed., Prentice Hall Financial Times.

Macmillan, H., \&Tampoe, M. (2000). Strategic Management, Oxford University Press.

Michael, B., Marije, B., Ivan, C., Luigi, C., Tim, P., Dominic, S., Nico, J., Paule Moustier, Laura Prota, Siebe Van Wijk. (2010). Making Value Chains Work better For the Poor. A Tool book for Practitioners of Value Chain Analysis. The Asian Development Bank (ADB) Resource Centre (GF02, 23 Phan Chu Trinh, Hanoi).

Mpagalile, J. J., Ishengoma, R., \& Gillah, P. (2008). Agribusiness Innovation; In Six African Countries the Tanzanian Experience. Agribusiness Innovation Forum Dar Es Salaam Monday, 12 May 08.

Mpagalile, J. J., Laswai, H. S., Silayo, V. C. K., Balegu, W. R, Mtunda, K., Chilosa, D., \& Nyborg, I. (2007). Post harvest research on sweet potato and cassava: An experience from Sokoine University of Agriculture (SUA), Morogoro, Tanzania. Pp 1-35. Tropical Root and Tuber Crops: Opportunities for Poverty Alleviation and Sustainable Livelihoods in Developing Countries. Proceedings of the Thirteenth Trienial Symposium of the International Society for Tropical Root Crops (ISTRC), Arusha, 10-14th November 2003.

Ndunguru, G. T. (2001). Influence of Quality Attributes on the Market Value of Flesh Sweet Potato Tubers and Processed in Cassava Mwanza and Morogoro, Dissertation for the Awards of PhD Degree at Sokoine University of Agriculture, Morogoro, Tanzania and Natural Resource Institute of Greenwich. 155.

Ndunguru G. T. (2003). Handling of Sweet Potato During Marketing. In: Cassava and Sweet Potato after Harvesting. Editors: Ngazi, H., Joram F., Placid J.,Ngendello, T. and Van Oirschot, Q. Proceedings of a Workshop held at the Lake Zone Agricultural Research and Development Institute, Ukiriguru, Mwanza Tanzania, 29 April 2002.

Orodho, A. B., Alela, B. O., \& Wanambacha, J. W. (1995). Use of sweet potato (Ipomoea batatas L.) vines as starter feed and partial milk replacer for calves. KARIKakamega, Kenya.

Pathania-Jain, G. (2001). Global parents, local partners: A value-chain analysis of collaborative strategies of media firms in India. Journal of Media Economics, 14(3), 169-187. http://dx.doi.org/10.1207/S15327736ME1403_3

Porter, M. E. (1985). Competitive Advantage: Creating and Sustaining Superior Performance, New York: Free Press.

Porter, M. E. (1990). The competitive advantage of nations, New York: Free Press.

Saunders, M., Lewis P., \& Thornhill A. (2004). Research Methods for Business Students. $2^{\text {nd }}$ Edition, Prentice Hall, New York.

Smith, M. (2004). Born-again crops give hope to Zimbabwean farmers [http://www.Zimbabwean+farmers:+Ian+Robertson+and...-a0126583061] site visited on 24/12/201.

Thomas Koenig (Team Leader), Jantje Blatt, Kristian Brakel, Kristina Kloss, Thorsten Nilges, Franziska Woellert. Seminar für Ländliche Entwicklung (SLE) (2008). Market-driven development and poverty reduction value chain analysis of fresh vegetables in Kenya and Tanzania. Nairobi, Berlin, January 2008. Deutsche Gesellschaft für Technische Zusammenarbeit (GTZ) GmbH-Beratungsgruppe Entwicklungsorientierte Agrarforschung (BEAF) African Insect Science for Food and Health (icipe) and The World Vegetable Center Regional Center for Africa (AVRDC-RCA). ISBN 3-936602-32-8

United Republic of Tanzania (URT). (2003b). Agricultural Sector Development Programme (ASDP): Framework and Process Document, March, Dar - Es - Salaam.

United Republic of Tanzania (URT). (2007b). Shinyanga Region Social-Economic Profile. Joint publication by National Bureau of Statistics and Shinyanga Regional Commissioner's Office, Coordinated by The President Office Planning and Privatization, Dar es Salaam. 28-284.

United Republic of Tanzania (URT). (2005). National Strategy for Growth and Reduction of Poverty. Government Printer DSM, 4.

United Republic of Tanzania (URT). (2007). Household Budget Survey, Dar-Es-Salaam, Tanzania.

United Republic of Tanzania (URT). (2004). The Economic Survey. Ministry of Agriculture and Food Security and Cooperatives, Dar-Es-Salaam, 11. 
United Republic of Tanzania (URT). (2011). Country review report. Tanzania Agricultural Food Security Investment Plan (TAFSIP). Government Printer DSM, 12.

Table 1. Percentage distribution of the age of sampled respondents

\begin{tabular}{|c|c|c|}
\hline Age & Frequency & Percent \\
\hline 28.10 & 33 & 22.0 \\
\hline $29-39$ & 42 & 28.0 \\
\hline $40-50$ & 58 & 38.7 \\
\hline $51-61$ & 10 & 6.7 \\
\hline $62-72$ & 7 & 4.7 \\
\hline Total & 150 & 100.0 \\
\hline
\end{tabular}

(Own survey, 2011)

Table 2. Percentage distribution of the Gender of sampled respondents

\begin{tabular}{|c|c|c|}
\hline Age & Frequency & Percent \\
\hline Male & 67 & 44.7 \\
\hline Female & 83 & 55.3 \\
\hline Total & 150 & 100.0 \\
\hline
\end{tabular}

(Own survey, 2011)

Table 3. Percentage distribution of the of sampled respondents by Marital status

\begin{tabular}{|c|c|c|}
\hline Marital status & Frequency & Percent \\
\hline Single & 17 & 11.0 \\
\hline Married & 129 & 86.0 \\
\hline Divorced & 1 & 1.0 \\
\hline Widow/widower & 3 & 2.0 \\
\hline Total & 150 & 100.0 \\
\hline
\end{tabular}

(Own survey, 2011)

Table 4. Percentage distribution of the of sampled respondents and Education level of sweet potatoes producers in terms of number of years in school

\begin{tabular}{|c|c|c|}
\hline Number of years & Frequency & Percent \\
\hline $0-3$ & 30 & 20.0 \\
\hline $4-7$ & 104 & 69.3 \\
\hline $8-11$ & 12 & 8.0 \\
\hline $12-15$ & 4 & 2.7 \\
\hline Total & 150 & 100.0 \\
\hline
\end{tabular}

(Own survey, 2011)

Table 5. Percentage distribution of the of sampled respondents and Amount of sweet potatoes produced, consumed and price

\begin{tabular}{|c|c|c|c|c|c|}
\hline & N & Min & Max & Mean & Std.Dev \\
\hline Amount of sweet potatoes produced (Kg) & 150 & 42.00 & 8100.00 & 767.313 & 1146.75 \\
\hline Amount of sweet potatoes consumed $(\mathrm{Kg})$ & 136 & 2.50 & 60000.00 & 3370.42 & 12019.00 \\
\hline Price of sweet potatoes $(\mathrm{Kg})$ & 31 & 200.00 & 140000.0 & 46070.96 & 41654.72 \\
\hline
\end{tabular}

(Own survey, 2011) 
Table 6. Percentage distribution of the of sampled respondents and Land cultivated of the sample respondents

\begin{tabular}{|c|c|c|}
\hline Land cultivated & Frequency & Percent \\
\hline $1-15$ & 128 & 85.3 \\
\hline $16-30$ & 13 & 8.7 \\
\hline $31-45$ & 4 & 2.7 \\
\hline $46-60$ & 5 & 3.3 \\
\hline Total & 150 & 100.0 \\
\hline
\end{tabular}

(Own survey, 2011)

Table 7. Equipment/tools possessed and sampled farmers

\begin{tabular}{|c|c|c|}
\hline Farming equipment/tools & Frequency & Percent \\
\hline Hand hoe & 121 & 80.7 \\
\hline Oxen plough & 29 & 19.3 \\
\hline Total & 150 & 100.0 \\
\hline
\end{tabular}

(Own survey, 2011)

Table 8. Percentage distribution of the of sampled respondents and cost involved in making ridging and planting

\begin{tabular}{|c|c|c|c|c|}
\hline & N & Minimum & Maximum & Mean \\
\hline Cost for making ridges matuta per acre & 118 & 1500.00 & 100000.00 & 28415.25 \\
\hline Costs of planting per acre & 112 & 1000.00 & 60000.00 & 20053.57 \\
\hline
\end{tabular}

(Own survey, 2011)

Table 9. Percentage distribution of the of sampled respondents and Costs of planting and weeding

\begin{tabular}{|c|c|c|c|c|c|}
\hline & $\mathbf{N}$ & Minimum & Maximum & Mean & Std.Deviation \\
\hline Cost of weeding & 132 & 3000.00 & 60000.00 & 25757.57 & 14777.80 \\
\hline
\end{tabular}

(Own survey, 2011)

Table 10. Percentage distribution of the of sampled respondents and Cost of harvesting

\begin{tabular}{|c|c|c|c|c|}
\hline & $\mathrm{N}$ & Min & Max & Mean \\
\hline Cost of harvesting & 120 & 7000.00 & 400000.00 & 31091.66 \\
\hline
\end{tabular}

(Own survey, 2011)

Table 11. Percentage distribution of the of sampled respondents and Market information

\begin{tabular}{|c|c|c|}
\hline & Frequency & Percent \\
\hline Direct visit to the market & 67 & 44.7 \\
\hline Cross check with fellow farmers & 76 & 50.7 \\
\hline Hear from friends & 4 & 2.7 \\
\hline From extension officers & 2 & 1.3 \\
\hline From NGO & 1 & 0.7 \\
\hline Total & 150 & 100.0 \\
\hline
\end{tabular}

(Own survey, 2011)

Table 12. Percentage distribution of the of sampled respondents and Input accessibility

\begin{tabular}{|c|c|c|}
\hline & Frequency & Percent \\
\hline Village extension officer & 29 & 19.3 \\
\hline NGO & 2 & 1.3 \\
\hline Input supplier & 14 & 9.3 \\
\hline No & 105 & 70.0 \\
\hline Total & 150 & 100.0 \\
\hline
\end{tabular}

(Own survey, 2011) 
Table 13. Estimated production of sweet potatoes (tonnes) in Shinyanga Rural

\begin{tabular}{|c|c|c|c|}
\hline Season & $\begin{array}{c}\text { Hectors under sweet } \\
\text { potatoes }\end{array}$ & $\begin{array}{c}\text { Production (Fleshed Sweet } \\
\text { Potatoes) }\end{array}$ & $\begin{array}{c}\text { Production of processed } \\
\text { products (dried) }\end{array}$ \\
\hline $2005 / 2006$ & 9427 & 28281 & 9050 \\
\hline $2006 / 2007$ & 13379 & 40137 & 12844 \\
\hline $2007 / 2008$ & 11243 & 33729 & 10793 \\
\hline $2008 / 2009$ & 13399 & 40197 & 12863 \\
\hline $2009 / 2010$ & 9476 & 28428 & 9097 \\
\hline
\end{tabular}

Source: District Agricultural and Livestock Officer (DALDO) office, Shinyanga Rural, 2010.

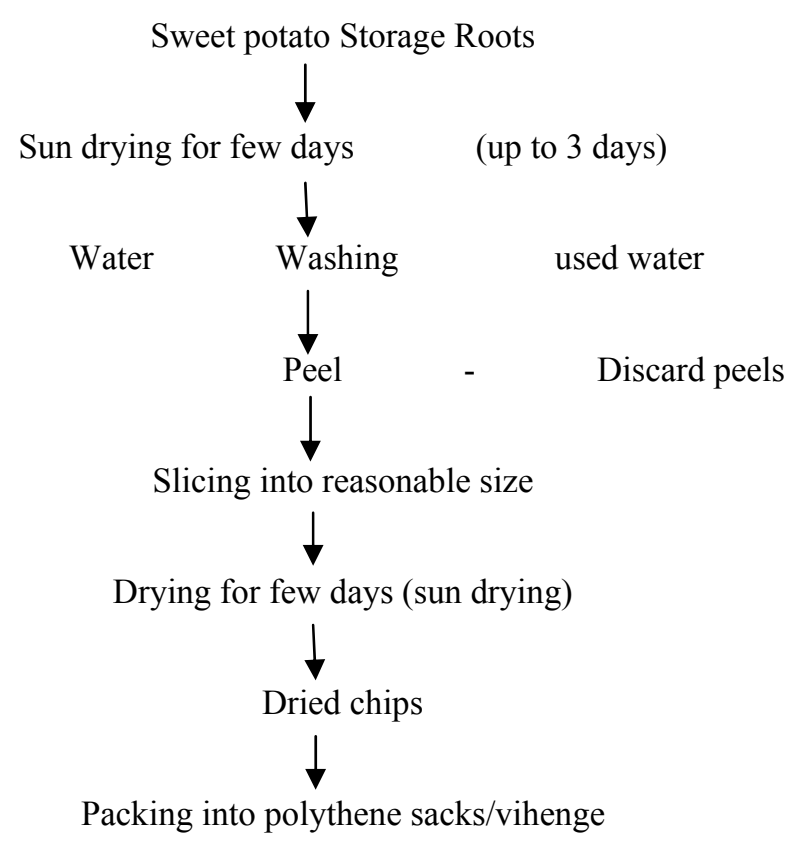

Figure 1. Process flow diagram for producing dried sweet potato chips "michembe" or "mapalage"

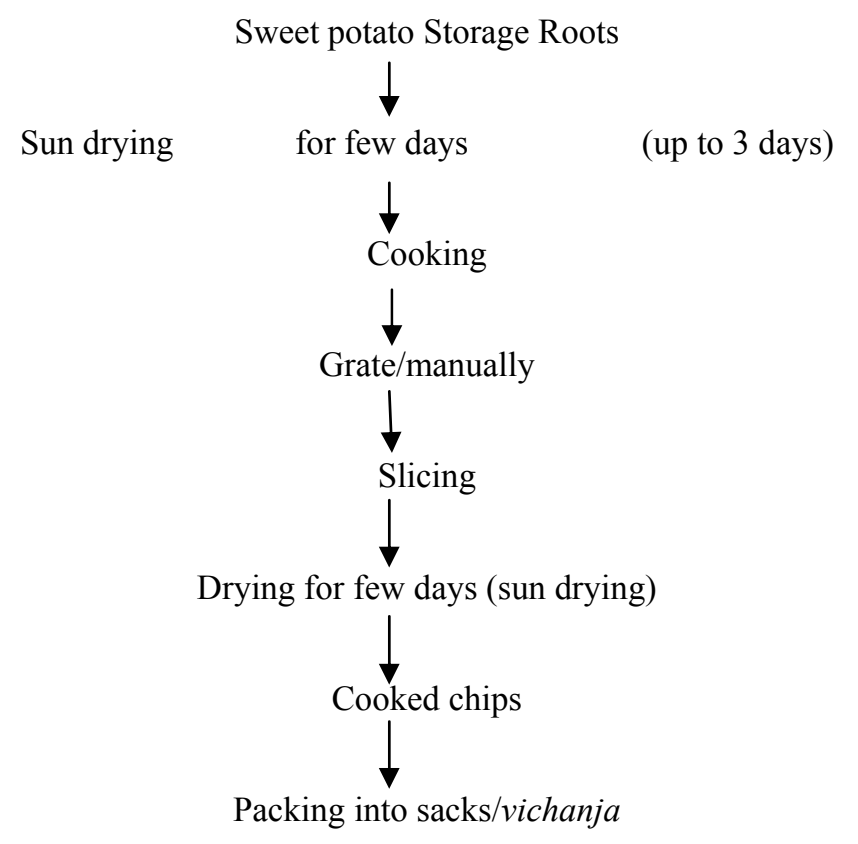

Figure 2. Process flow diagram for producing dried sweet potato chips "Matobolwa" 


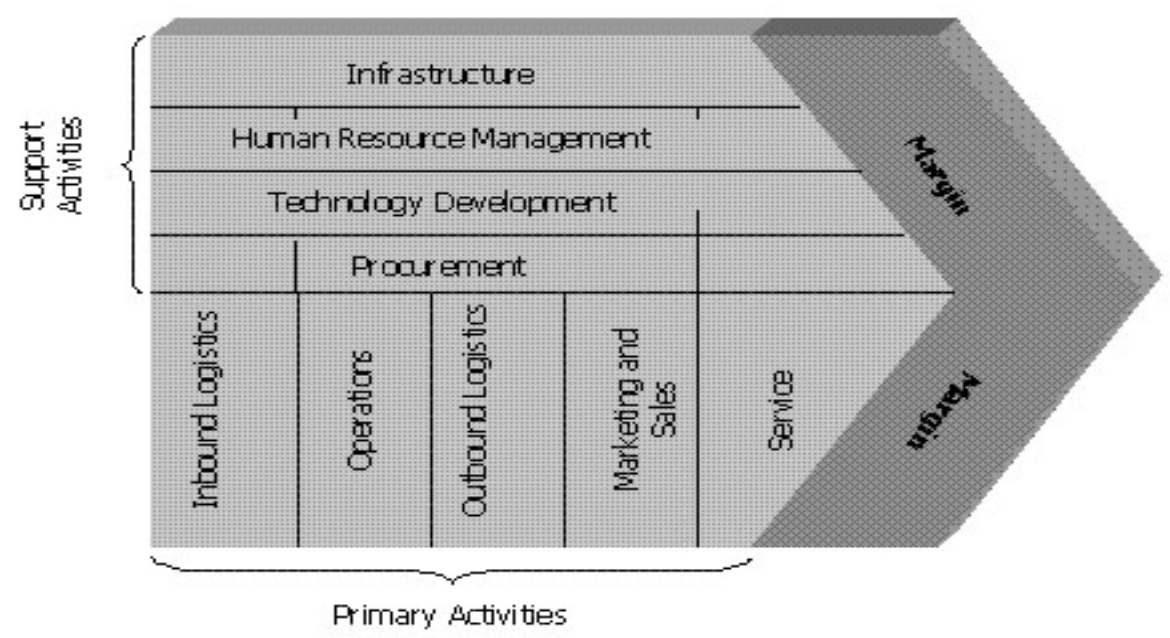

Source: Porter (1985)

Figure 3.The Value Chain concept

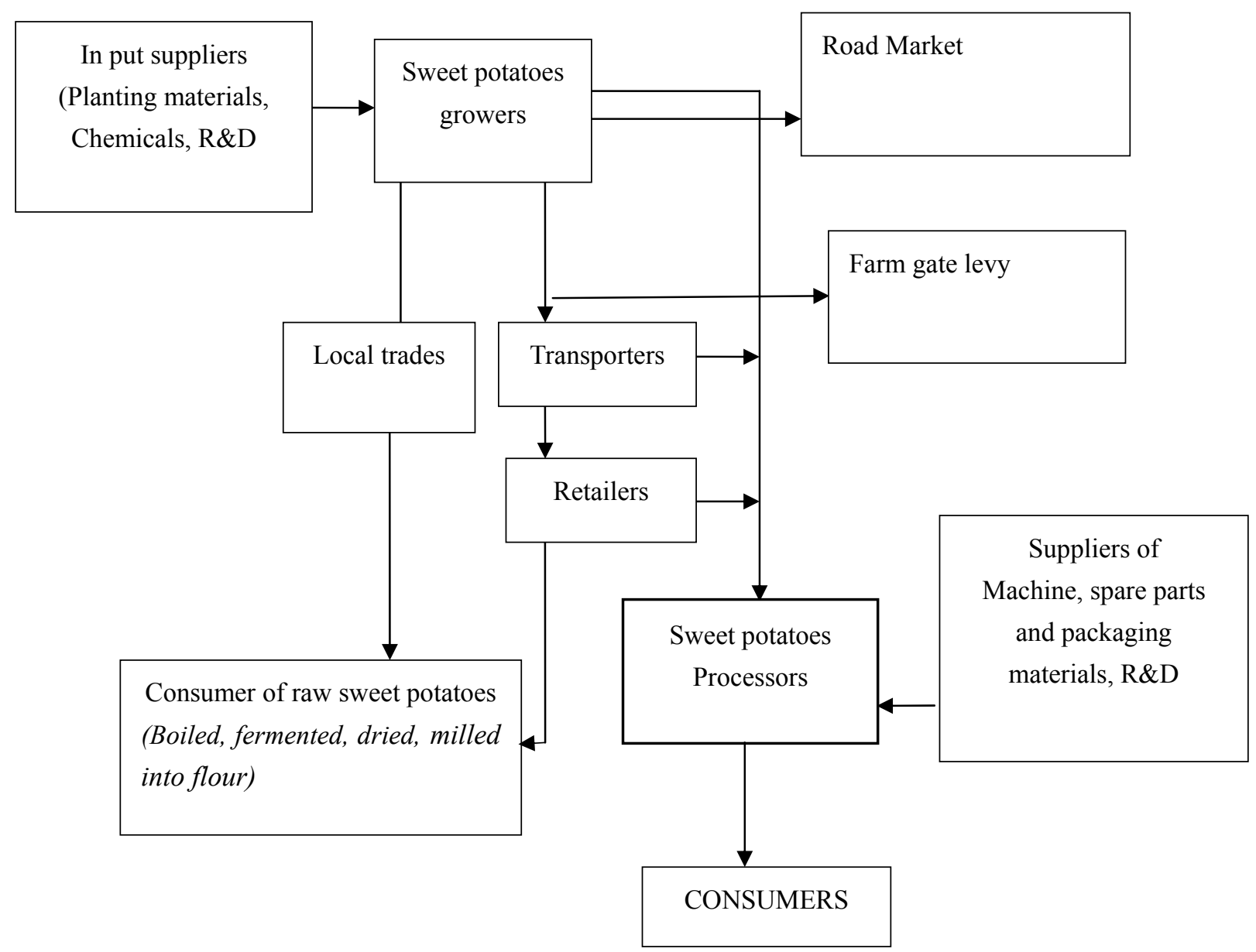

Figure 4. Conceptual framework for sweet potato value chain in Tanzania

Source: Modified from (Mpagalile et al., 2008). Agribusiness Innovation Forum. 

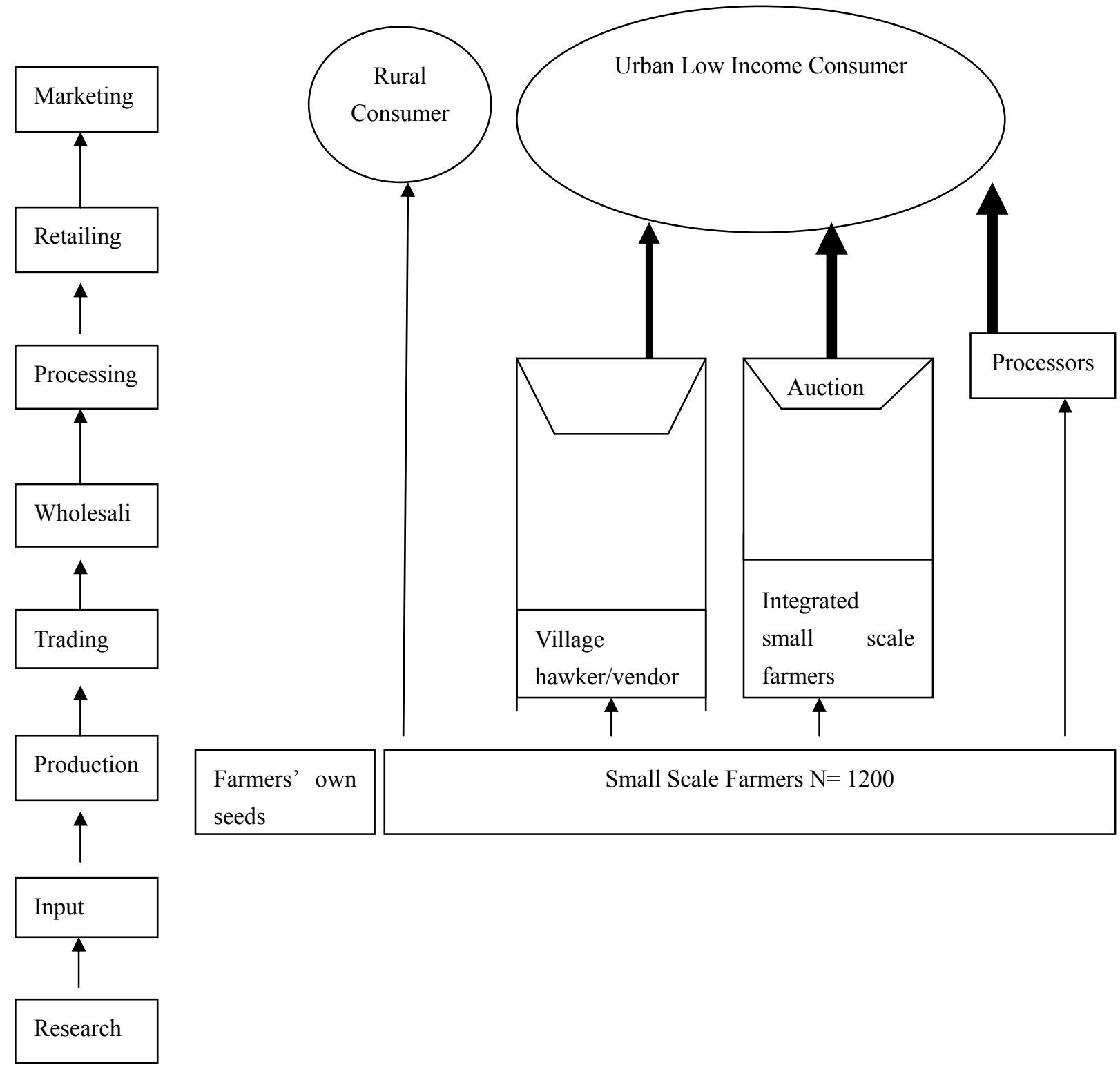

Farmers' own
seeds

Figure 5. Sweet potato subsector dynamics

Source: Modified from SNV Tanzania. Fresh Fruits Sub sector study Final report July, 2005. 

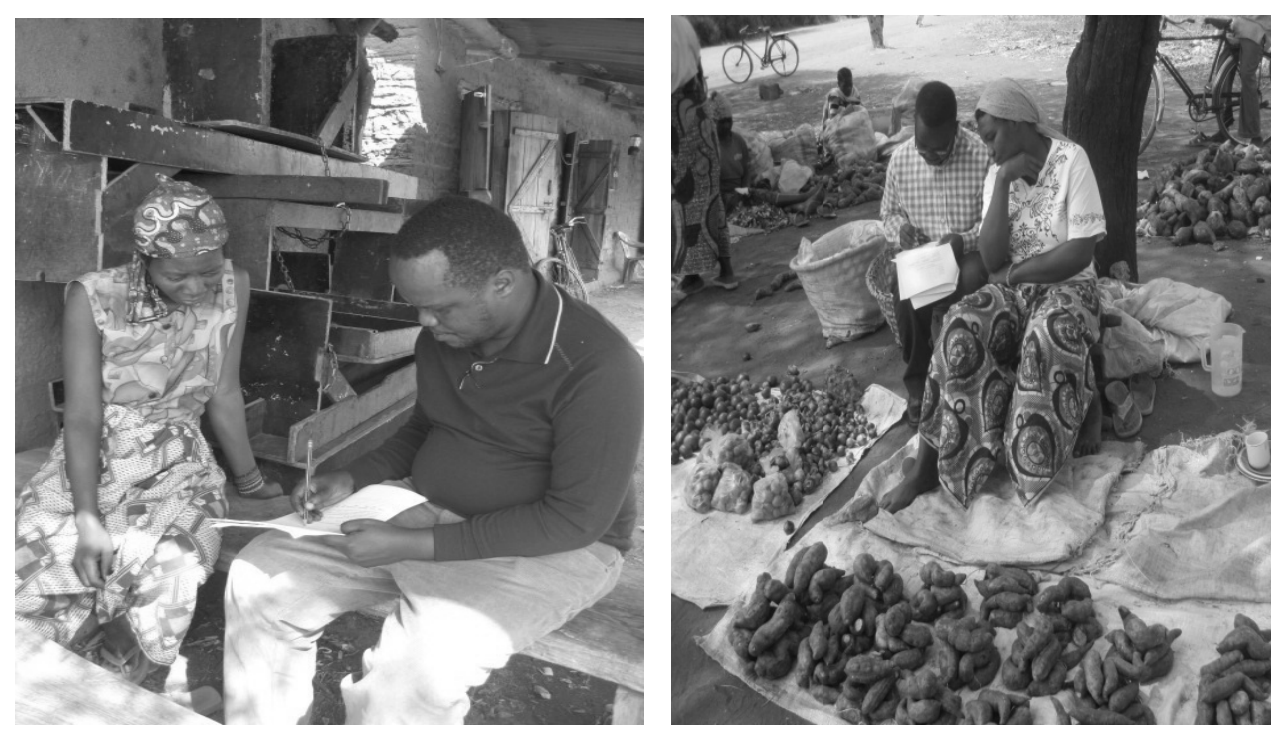

Figure 6. Principal researcher Mr. Joel. J. Mmasa conducting an interview at Iselamagazi village, Iselamagazi wards Shinyanga rural District (Left side picture). Picture in the right side shows researcher assistant Mr. Morgan Brightone conducting face to face interview with retailer at Shinyanga urban market, the picture also shows the bunch of products displayed ready for selling. The produce were sold at TAS 500 to TAS 1000 per assortment

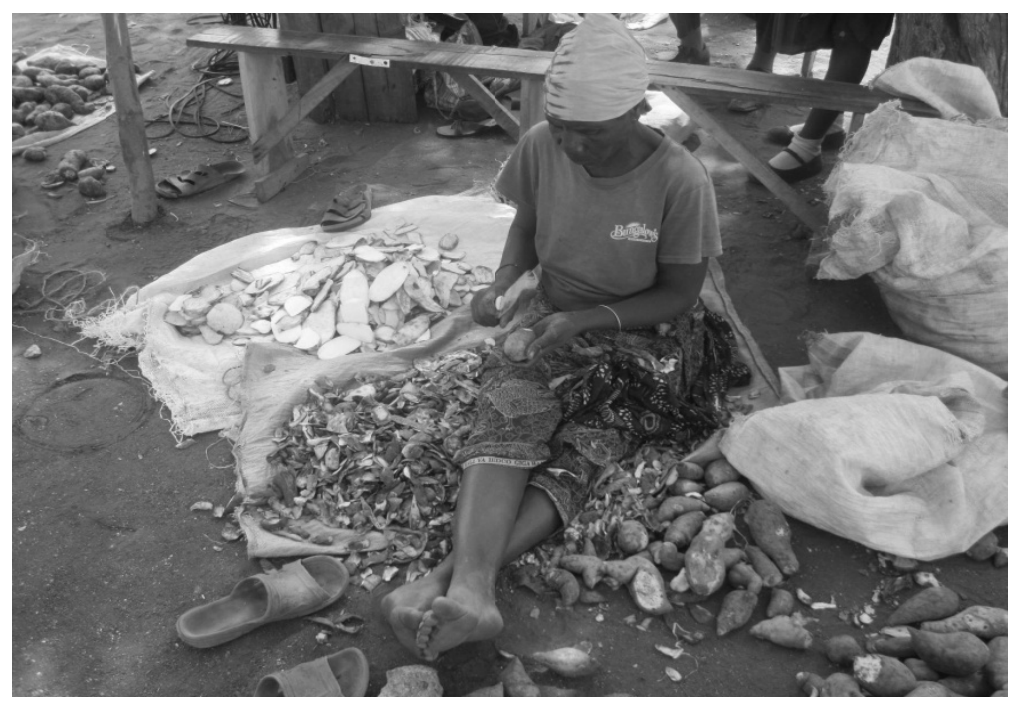

Figure 7. The picture above shows the woman hired by retailers to prepare "michembe" at the local market place in Shinyanga urban to increase shelf life of the produce 